\section{Acute intermittent porphyria and Caesarean delivery}

A 29-yr-old patient was diagnosed with acute intermittent porphyria (AIP) during pregnancy. She had a Caesarean section under lidocaine/fentanyl epidural blockade. Because of inadequate analgesia, general anaesthesia was induced with propofol. Postoperatively urinary porphobilinogen excretion 1625 $\mu \mathrm{mol} \cdot$ day ${ }^{-1}$ ) exceeded the upper limit of normal but no symptoms of porphyria developed. In anecdotal clinical reports and in a previously described rat model of porphyria, propofol was found to be safe. This is the first reported use of propofol in a pregnant porphyric patient. Anaesthetic drug safety in porphyria is reviewed and the choice of induction agent discussed. Data on which to base these decisions is limited but we conclude that propofol may be suitable for use in patients with porphyria.

Une porphyrie intermittente aigue fut diagnostiquée chez une patiente de 29 ans pendant la grossesse. On procéda à une césarienne sous bloc épidural avec lidocaïne et fentanyl. Suite à une analgésie inadéquate, une anesthésie générale fut induite avec le propofol. Aucun symptôme de porphyrie n'est apparu, malgré une excrétion postopératoire de porphobilinogène urinaire de $625 \mu \mathrm{M} \cdot$ jour $^{-1}$, excédant la limite supérieure de la normale. Il a été démontré que le propofol est sécuritaire lors de cas cliniques anecdotiques et dans un modèle de porphyrie chez les rats. La présente publication est la première concernant l'utilisation de propofol chez la patiente enceinte porphyrique. Face à la porphyrie, la sécurité des agents anesthésiques est revue et le choix des agents anesthésiques est discuté. Les données servant à prendre ces décisions sont limitées, mais nous en concluons que le propofol peut être adéquat chez les patients atteints de porphyrie.

\section{Key words}

ANAESTHESIA: obstetric;

ANAESTHETICS: intravenous, propofol; COMPLICATIONS: porphyria.

From the Mount Sinai Hospital, Department of Anaesthesia, 600 University Avenue, Toronto, Ontario M5G 1 X5.

Address correspondence to: Dr. Stephen Rolbin, Department of Anaesthesia, Mount Sinai Hospital, 600 University Avenue, Toronto Ontario M5G 1 X5.

Accepted for publication 4th November, 1991.
Gareth Kantor MB ChB, Stephen H. Rolbin MD FRCPC

The term porphyria refers to a group of rare, genetically determined disorders characterised by overproduction of haeme precursors secondary to deficient enzyme activity in the haeme biosynthetic pathway.

The acute hepatic porphyrias, which include acute intermittent porphyria (AIP), variegate porphyria (VP) and hereditary coproporphyria (HCP), are of particular interest to anaesthetists because of the ability of certain anaesthetic agents to trigger life-threatening attacks of encephalopathy and muscle paralysis.

Laboratory data and several clinical reports suggest that propofol (Diprivan) may be safely used in these patients. We report the first use of propofol to induce general anaesthesia for Caesarean section in a patient with AIP.

\section{Case report}

This 29-yr-old G2,P1 patient was admitted at 29.5 wk gestational age because of spontaneous rupture of the membranes. At $32.5 \mathrm{wk}$ her non-stress test showed variable decelerations from a baseline of 150 to 60-70 beats $\cdot \mathrm{min}^{-1}$. Oxytocin was commenced and despite good contractions, cervical dilatation only progressed to $3 \mathrm{~cm}$.

The patient had been tested for porphyria in June 1990 after being warned by her father's sister that the gene was present in the family. At this time she was asymptomatic and in the first trimester. She tested positive; $24 \mathrm{hr}$ urinary porphobilinogen excretion was $388 \mu \mathrm{mol} \cdot$ day $^{-1}(n=$ $0-15)$ and $\delta$-aminolevulinic acid was $356(n=0-53)$ $\mu \mathrm{mol} \cdot \mathrm{day}^{-1}$. In retrospect, she remembered an episode of right upper quadrant pain in early 1989 and several unexplained episodes of abdominal pain when given "birth control pills." Thus the diagnosis of AIP was made.

At the time of induction of labour she had no symptoms and reported having had an uneventful epidural for her first labour with no postpartum symptoms. An epidural anaesthetic was performed for this labour (12 $\mathrm{ml} \mathrm{bu}$ pivacaine $0.25 \%$ after a test dose of $2 \mathrm{ml}$ lidocaine $2 \%$ $\mathrm{HCL}$ ). Because of failure to progress, she presented for Caesarean section and received $25 \mathrm{ml}$ lidocaine $\mathrm{CO}_{2}$ and $50 \mu \mathrm{g}$ fentanyl. Sensory level of the block was established at $\mathrm{T}_{3-4}$ (alcohol swab) and surgery proceeded satisfactorily until the obstetricians started to manipulate the uterus. A decision was made to induce general anaesthesia because of her extreme discomfort. Anaesthesia was induced with 
$120 \mathrm{mg}$ propofol and $100 \mathrm{mg}$ succinylcholine was given to facilitate tracheal intubation. Anaesthesia was maintained with isoflurane 0.6 to $1.0 \%$ (insp). The infant weighed $1440 \mathrm{~g}$ and had one and five minute Apgar scores of seven and nine. Before completion of surgery she received $4 \mathrm{mg}$ epidural morphine and the trachea was extubated when she was awake at the completion of surgery. The post partum course was uneventful.

A $24 \mathrm{hr}$ urine sample was collected on the first postpartum day and the porphobilinogen level was 625 $\mu \mathrm{mol} \cdot \mathrm{day}^{-1}(n=<15)$.

\section{Discussion}

Pathogenesis of porphyria

Porphyria is a genetic disorder manifested by a deficiency in enzyme activity in the haeme biosynthetic pathway. Induction of the rate-limiting step, the enzyme ALAsynthetase, results in increased haeme precursor production which overwhelms the defective enzyme. Induction of the hepatic cytochrome P450 system, a series of haemoprotein isoenzymes, by lipid-soluble drugs such as barbiturates creates a need for increased haeme biosynethesis. Enhanced activity of ALA-synthetase then occurs either by direct stimulation or by depression of enzyme activity.,2

The defect in AIP resides in the enzyme porphobilinogen deaminase (PBG-deaminase). The precursors ALA and PBG accumulate and are released from the liver into the circulation. During acute attacks the levels of urinary ALA and PBG are increased. During the latent period the urinary excretion of ALA and PBG decreases, but rarely reaches normal values. An erythrocyte PBGdeaminase assay is available but few carriers express the clinical phenotype; the assay is useful in genetic screening, not in the clinical diagnosis. ${ }^{3}$

The pathogenesis of the neurological manifestations of acute attacks of porphyria is believed to be similar in all four of the hepatic porphyrias. ${ }^{2}$ Neurotoxicity may be due to the direct effects of ALA and PBG, or to neuronal haeme deficiency. ALA is closely related to GABA structurally and may interact with receptors to block normal GABA neurotransmission. Pathologically, both demyelination and axonal degeneration have been described in peripheral nerves and autonomic nervous tissue, and, less extensively, in the CNS. ${ }^{4}$ The peripheral neuropathy which occurs is predominantly motor (distal weakness and respiratory muscle paralysis) and may also affect the cranial nerves (bulbar paralysis). The autonomic neuropathy may result in labile blood pressure, orthostatic hypotension, vasospasm and diaphoresis, and the severe abdominal pain which is the hallmark of the acute attack. Central nervous system involvement may present as seizure activity, depression or as an acute organic brain syndrome (confusion, delusions and hallucinations). ${ }^{4-7}$

\section{Pregnancy and porphyria}

Most symptomatic patients with porphyria are female. Attacks may be precipitated by menstruation, pregnancy and oral contraceptives but are rare after the menopause. ${ }^{8,9}$ Female sex hormones may act as inducers of ALAsynthase. ${ }^{8}$ Normal pregnancy is associated with urinary excretion of ALA, PBG and porphyrins that is $15-60 \%$ greater than in nonpregnant females. ${ }^{10,11}$ The magnitude of these changes is much smaller than during porphyric attacks. Pregnancy in patients with AIP has been associated with a high incidence of acute attacks of porphyria (24-95\%), resulting in considerable mortality (2-42\%) and high rates of spontaneous abortion (6-12\%), hypertension $(16 \%)$ and low birth weight infants. ${ }^{8}$

\section{Anaesthetic considerations}

The safety of drugs in porphyria may be assessed on the basis of clinical reports which link their administration to the subsequent development of the symptoms of an acute attack. Anecdotal reports of safe use do not guarantee safety; even well-known triggers such as the barbiturates do not consistently precipitate reactions. ${ }^{12}$ Conversely, reactions may be triggered by starvation, stress or mild pyrexial illness in the absence of any drug treatment. ${ }^{13,14}$

Drugs may be evaluated in rats with chemically induced porphyria, and in normal rats, for their ability to stimulate activity of the haeme biosynthetic pathway. Drug metabolism may differ radically from humans, however. In fact, interspecies variations in the response of the haeme biosynthetic pathway to drugs are noted even between rats and mice. ${ }^{15}$

Parikh and Moore compared the porphyrinogenicity in rats of propofol with phenobarbitone, a "standard" triggering agent. ${ }^{16}$ Animals given phenobarbitone showed increases in the activity of ALA synthase and in total liver porphyrins whereas propofol caused no changes. This enhancement of porphyrin synthesis by phenobarbitone simulates the increased activity of the haeme pathway in porphyria. Rats that received propofol after two days of "pre-induction" with phenobarbitone showed no difference in porphyrin levels compared to rats that received only phenobarbitone. Propofol is not porphyrinogenic in this model, suggesting that it may be suitable for use in porphyric patients.

Propofol has been used in patients with AIP $(n=6),{ }^{17-21}$ hereditary coproporphyria $(n=1)^{22}$ and variegate porphyria $(n=14))^{23,24}$ There were no episodes of porphyric reactions and urinary porphyrins either decreased or were unchanged postoperatively. One report has described a patient with hereditary coproporphyria in whom 20 out of 
22 previous general anaesthetics had resulted in abdominal pain and neurological symptoms. ${ }^{22}$ She received propofol $270 \mathrm{mg}$ for a gynaecological procedure and showed a decrease in urinary porphyrin excretion postoperatively. In another patient with variegate porphyria, the porphobilinogen level increased marginally after propofol anaesthesia. ${ }^{23-25}$ While these data do not establish conclusively the safety of propofol in porphyria, they do not suggest that it triggers acute reactions.

Barbiturates are uniformly considered to be contra-indicated in porphyria although a retrospective study of patients exposed to barbiturates for general anaesthesia revealed that the risk may be low in those who are not symptomatic at the time of surgery. ${ }^{12}$ The safe use of etomidate has been reported ${ }^{29}$ and it is not porphyrinogenic after a single dose in a rat model ${ }^{27}$ but toxicity may be dose-related ${ }^{30}$ and the drug should probably be avoided. ${ }^{5,11,26}$ Acute porphyric reactions have been associated with the use of benzodiazepines, and laboratory evidence of porphyrinogenicity exists for diazepam and flunitrazepam. ${ }^{27,28}$ Midazolam has been used successfully in 14 patients with variegate porphyria, ${ }^{31}$ but is not suitable for induction of obstetric anaesthesia. ${ }^{32}$ Ketamine has been reported as dangerous by only one author and did not increase ALA-synthase activity in rats after multiple doses and after infusion. ${ }^{28,30}$ Ketamine has been used to induce general anaesthesia for Caesarean section in a patient with AIP. ${ }^{33}$

Other anaesthetic agents are reviewed elsewhere. Most authors consider that inhalational agents, ${ }^{15,34}$ narcotics $5,14,15,26,27$ depolarizing and non-depolarizing muscle relaxants, ${ }^{2,5,15,41}$ local anaesthetics including lidocaine and bupivacaine $e^{15,34-36}$ and anticholinesterases ${ }^{2}$ do not trigger porphyric reaction.

Anaesthesia for the pregnant patient presents additional considerations. Propofol may be a suitable alternative to thiopentone as an induction agent for anaesthesia in elective Caesarean section, ${ }^{37-40,42}$ but is not yet recommended by the manufacturers for this purpose. ${ }^{43}$ Indeed one authority questions its use for routine Caesarean delivery. ${ }^{44}$ In spite of this, we believe it to be a suitable induction agent in the pregnant patient with AIP.

Either a regional or a general anaesthetic may be given to the patient with AIP. The patients should be seen before their anaesthetic and informed regarding the risks of AIP and anaesthesia. Patient education is an important benefit of such a meeting. The risks and benefits of epidural analgesia for labour or Caesarean delivery need to be explained. For example, a high risk obstetrical patient may greatly benefit from epidural anaesthesia. The use of regional anaesthesia is not contraindicated as long as the possibility of autonomic dysfunction is considered. ${ }^{14}$

\section{Conclusion}

We chose propofol to induce anaesthesia in this patient because laboratory evidence and (limited) clinical experience suggested that it does not trigger acute porphyric reactions, and because propofol is a suitable induction agent for anaesthesia in elective Caesarean section. ${ }^{37-40}$ The elevation in urinary PBG postoperatively may raise some concern about the safety of propofol in patients with porphyria. However, there were no clinical manifestations of acute porphyria and PBG levels in this asymptomatic patient were extremely elevated well before surgery.

We conclude that propofol may be a suitable agent for use in AIP although the data do not allow any definite conclusion about its safety.

\section{References}

1 Kappas A, Sassa S, Galbraith RA, et al. The Porphyrias. In: Scriver CR, Beaudet AL, Sly WS, et al. (Eds.). The Metabolic Basis of Inherited Disease. 6th ed., New York: McGraw-Hill, 1989; 1305-65.

2 Bloomer JR, Bonkovsky $H L$. The porphyrias. Diseases of the Month 1989; 35: 13-54.

3 Kushner IP. Laboratory diagnosis of the porphyrias. N Engl J Med 1991; 324: 1432-4.

4 Becker DM, Kramer $S$. The neurological manifestations of porphyria: a review. Medicine 1977; 56: 411-23.

5 Stoelting RK, Dierdof SF, McCammon RL. (Eds.) Metabolism and Nutrition: In: Anesthesia and Co-existing Disease. 2nd ed. New York: Churchill Livingstone, 1988; 529-32.

6 Laiwah MY, MacPhee GJA, Boyle P, et al. Autonomic neuropathy in acute intermittent porphyria. J Neurol Neurosurg Psych 1985; 48: 1025-30.

7 Greenspan GH, Block AJ. Respiratory insufficiency associated with acute intermittent porphyria. S Med J 1981; 74: 954-6.

8 Kanaan C, Veille JC, Lakin M. Pregnancy and acute intermittent porphyria. Obstet Gynecol Surv 1989; 44: $244-9$.

9 Braunwald E, Isselbacher KJ, Petersdorf RG, et al. (Eds.). Harrison's Principles of Internal Medicine. 11th ed. New York: McGraw Hill, 1987; 1638-43.

10 Lyberatos C, Chalevelakis G, Platis A, et al. Urinary porphyrins and their precursors in human pregnancy and after delivery. J Obstet Gynecol B Commwlth 1972; 79: 921-3.

11 De Klerk M, Weideman A, Malan C, et al. Urinary porphyrins and porphyrin precursors in normal pregnancy. $S$ Afr Med J 1975; 49: 581-3.

12 Mustajoki PM, Heinonen J. General anesthesia and inducible porphyrias. Anesthesiology 1980; 53: 15-20. 
13 Disler $P B$, Eales $L$. The acute attack of porphyria. S Afr Med J 1981; 61: 82-3.

14 Carp H, Clark B. Genetic and metabolic disease. In Datta $S$ (Ed.). Anesthetic and Obstetric Management of High Risk Pregnancy. 1st ed. St. Louis: Mosby Year Book 1991; 31-2.

15 Disler PB, Blekkehhorst GH, Eales L, et al. Guidelines for drug prescription in patients with the acute porphyrias. S Afr Med J 1982; 61: 656-60.

16 Parikh RK, Moore MR. A comparison of the porphyrinogenicity of di-isopropylenol (propofol) and phenobarbitone. Biochem Soc Trans 1986; 14: 726-7.

17 Mitterschiffthaler $G$, Theiner A, Hetzel $H$, et al. Safe use of propofol in a patient with acute intermittent porphyria. Br J Anaesth 1988; 60: 109-11.

18 Parr MJA, Hayden-Smith J. Propofol, porphyria and epilepsy. Anaesthesia 1990; 45: 594.

19 Haberer IP, Malthe $R$. Propofol in acute porphyria. Anaesthesia 1989; 44: 932.

20 Cooper $R$. Anaesthesia for porphyria using propofol. Anaesthesia 1988; 43: 611.

21 McLouglin C. Use of propofol in a patient with porphyria. Br J Anaesth 1989; 62: 114.

22 Hughes PJ. Propofol in acute porphyrias. Anaesthesia 1990; $45: 415$.

23 Meissner PN, Hift RJ, Harrison GG. Porphyria and propofol. Anaesthesia 1989; 44: 612-3.

24 Weir PM, Hodkinson BP. Is propofol a safe agent in porphyria? Anaesthesia 1988; 43: 1022-3.

25 McNeill MJ, Parikh RK, Moore MR. Propofol in acute porphyria. Anaesthesia 1989; 44: 532.

26 Moore MR, McColl KEL. Therapy of the acute porphyrias. Clin Biochem 1989; 22: 181-8.

27 Blekkenhorst GH, Harrison GG, Cook ES, et al. Screening of certain anaesthetic agents for their ability to elicit acute porphyric phases in susceptible patients. $\mathrm{Br} \mathbf{J}$ Anaesth 1980; 52: 759-62.

28 Parikh $P K$, Moore MR. Anaesthetics in porphyria: intravenous induction agents. Br J Anaesth 1975; 47: 907.

29 Famewo $C E$. Induction of anaesthesia with etomidate in a patient with acute intermittent porphyria. Can Anaesth Soc J 1985; 32: 171-3.

30 Harrison GG, Moore MR, Meissner PN. Porphyrogenicity of etomidate and ketamine as continuous infusions. $\mathrm{Br} \mathrm{J}$ Anaesth 1985; 57: 420-3.

31 Freedman $M$, Ingram HJ, Smuts JHL. Midazolam for induction of anaesthesia in patients with porphyria. S Afr Med J 1985; 68: 212.

32 Bland BAR, Lawes EG, Duncan PW, et al. Comparison of midazolam and thiopental for rapid sequence anesthetic induction for elective cesarean section. Anesth Analg 1987; 66: 1165-8.
33 Bancrofi $G H$, Lauria $J L$. Ketamine induction for cesarean section in a patient with acute intermittent porphyria and achondroplastic drwafism. Anesthesiology 1983; 59 : 143-4.

34 Parikh RK, Moore MR. Effect of certain anaesthetic agents on the activity of rat hepatic $\delta$-aminolaevulinate synthase. Br J Anaesth 1978; 50: 1099-102.

35 Brennan L, Halfacre JA, Woods SD. Regional anaesthesia in porphyria. Br J Anaesth 1990; 65: 594-7.

36 McNeill MJ, Bennet $A$. Use of regional anaesthesia in a patient with acute porphyria. Br J Anaesth 1990; 64: 371-3.

37 Gin T, Gregory MA, Chan K, et al. Maternal and fetal levels of propofol at Caesarean section. Anaesth Intensive Care 1990; 18: 180-4.

38 Gin T, Gregory MA, Oh TE. The hemodynamic effects of propofol and thiopentone for induction of Caesarean section. Anaesth Intensive Care 1990; 18: 175-9.

39 Moore J, Bill KM, Flynn RJ, et al. A comparison between propofol and thiopentone as induction agents in obstetric anaesthesia. Anaesthesia 1989; 44: 753-7.

40 Gregory MA, Gin T, Yau G, et al. Propofol infusion anaesthesia for Caesarean section. Can J Anaesth 1990; 37: 514-20.

$41 \operatorname{Lin} Y, C$ hen $L$. Atracurium in a patient with acute intermittent porphyria. Anesth Analg 1990; 71: 440-6.

42 Valtonen $M$, Kanto J, Rosenberg P. Comparison of propofol and thiopentone for induction of anaesthesia for elective caesarian section. Anaesthesia 1989; 44: 758-62.

43 ICI Pharma, Mississauga, Ontario LSN SR7. Product Monograph: Diprivan. June, 1990.

44 Celleno D. Capogna G. Tomassetti $M$, et al. Neurobehavioural effects of propofol on the neonate following elective Caesarean section. Br J Anaesth 1989; 62: 649-54. 